\title{
Reapropiación y articulación socio-cultural de santos y Vírgenes católicos en los Andes Sur Colombianos
}

Beatriz Nates Cruz

\author{
(2) OpenEdition \\ Journals \\ Edición electrónica \\ URL: http://journals.openedition.org/assr/20184 \\ DOI: 10.4000/assr.20184 \\ ISSN: $1777-5825$ \\ Editor \\ Éditions de l'EHESS
}

\section{Edición impresa}

Fecha de publicación: 1 abril 2001

Paginación: 27-44

ISBN: 2-222-96701-5

ISSN: 0335-5985

Referencia electrónica

Beatriz Nates Cruz, «Reapropiación y articulación socio-cultural de santos y Vírgenes católicos en los Andes Sur Colombianos", Archives de sciences sociales des religions [En línea], 113 | janvier-mars 2001, Publicado el 29 noviembre 2013, consultado el 19 abril 2019. URL : http://journals.openedition.org/ assr/20184; DOI : 10.4000/assr.20184

Este documento fue generado automáticamente el 19 abril 2019.

(c) Archives de sciences sociales des religions 


\title{
Reapropiación y articulación socio- cultural de santos y Vírgenes católicos en los Andes Sur Colombianos $^{1}$
}

\author{
Beatriz Nates Cruz
}

1 Partiendo de Popayán, la capital del departamento del Cauca, la llamada Ciudad Blanca ${ }^{2}$ de Colombia, y después de un día de transitar por un camino pedregoso y lleno de barro, el autobús comienza su larga y última subida hacia el Macizo Colombiano, tierra formada por un conjunto de valles y de altas planicies en la Cordillera Central. El Macizo Colombiano es considerado a nivel nacional la Estrella Fluvial Colombiana por dar origen a los principales ríos del país que proporcionan el $80 \%$ del agua que recibe casi toda Colombia. Está región montañosa es la tierra de campesinos e indígenas yanaconas ${ }^{3}$ quienes habitan allí desde antiguo.

2 Los indígenas y campesinos entre los cuales realicé el trabajo de campo fueron en total 8.137. En la actualidad todos estos habitantes son practicantes de la religión católica adaptada a la cosmovisión local. Los campesinos e indígenas yanaconas no hablan su idioma nativo presumiblemente el quechua y de su vestido tradicional sólo se mantiene la "ruana" o poncho elaborado de lana de oveja. 


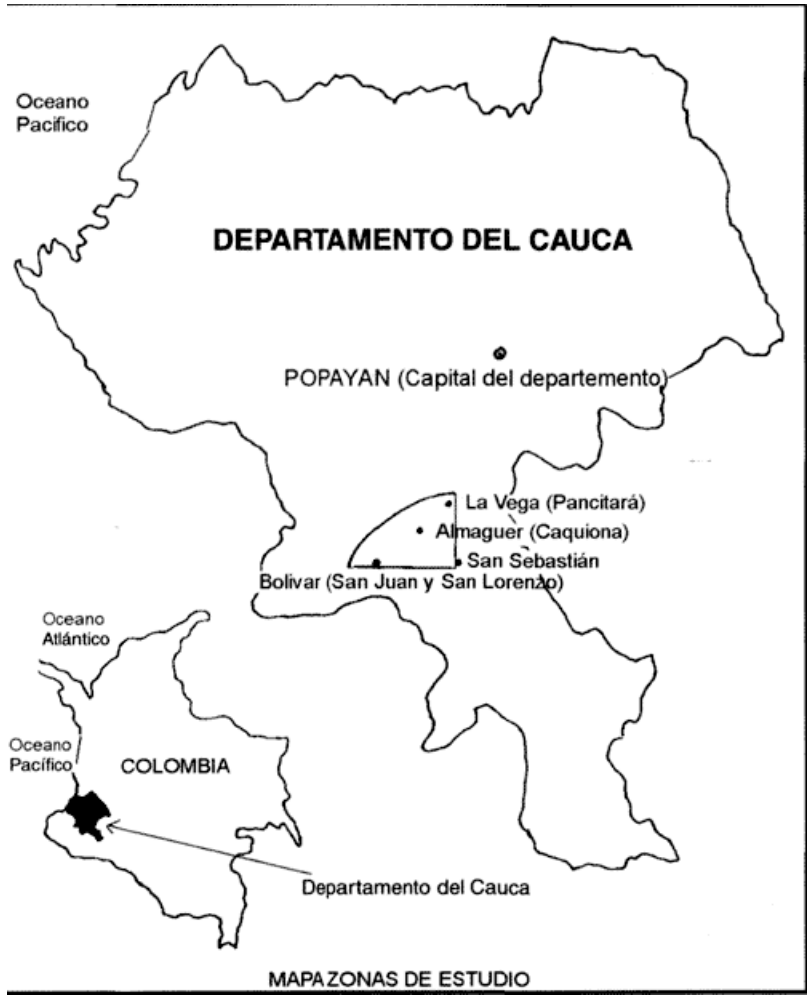

La discusión teórica que se ha dado hasta la actualidad sobre el tema de la reapropiación de imágenes católicas entre indígenas andinos (Bouysse Cassagne, 1984, 1988 ; Gisbert, 1980 ; Urbano, 1988 ; Wachtel, 1990, entre otros), se dirigen especialmente a mostrar y demostrar dos cuestiones fundamentales : en principio encontrar la autenticidad de estas imágenes bajo la legitimidad de un pensamiento andino y como segunda cuestión analizar cómo este tipo de imágenes y otras más, propias del espacio católico, fueron asumidas aparentemente por los amerindios, pero que en el fondo, sólo eran un pretexto para seguir rindiendo homenaje a sus antiguos cultos.

4 Si bien es cierto que los estudios sobre la legitimidad de las imágenes católicas bajo un pensamiento local, o la permanencia de los cultos antiguos a través de los venideros, han ayudado en gran medida a abrir otros caminos de estudios y a profundizar en ellos, no podemos olvidar que el culto de imágenes católicas con toda la parafernalia de mitos, leyendas y ritos al respecto, tienen un referente de difusión y es para nuestro caso el espacio ibérico. Es por ello que buscar la autenticidad de estos cultos en los Andes, impide el rico análisis que se podría hacer si consideráramos mejor los estudios bajo la discusión de una reapropiación de la cultura venidera bajo los contextos locales. En un trabajo reciente Thérèse Bouysse-Cassagne (1997, pp. 157-212) hace un esfuerzo diferente en el análisis de nuestro tema sobre el mismo espacio, los Andes. La pregunta de cómo tuvo lugar esto que ella llama sincretismo y que yo prefiero nombrar reapropiación y reescritura ${ }^{4}$ , la lleva a preguntarse por los antiguos cultos mediterráneos que fueron buscados por los misioneros en la América Prehispánica y en este afán asimilados a muchos cultos locales con tal de legitimar la expansión de la historia sagrada. Este estudio es de nuestro interés por cuanto busca las dos miradas y avanza en la discusión de aceptar que se trata de un análisis de los hoy cultos andinos, pero cristianos también : "Al mismo tiempo que los españoles construían nuevos mitos, los andinos interpretaban a su turno las 
representaciones cristianas apropiándoselas. Estas dos caras de la misma moneda se influenciaron mutuamente, formando parte de un solo e inacabable proceso que perdura hasta hoy » (1997, p. 191). Pero no se puede olvidar que toda esta puesta en escena de lo de aquí y lo de allá se enmarca dentro de lo que Wiliam Christian ha llamado la Religión Local (1981). Esto es, una forma de expresión religiosa que se hace presente a diferentes escalas dentro del conjunto del mundo cristiano. Este tipo de religión, tiene según el autor, su punto de partida en el culto de santos o de la Virgen propio de pequeños espacios sociales tales como una ciudad, un pueblo, etc. Es importante traer este concepto aquí, ya que toca directamente el presente artículo: por un lado este concepto es elaborado como el producto de un trabajo de investigación sobre Castilla, punto de referencia de los cultos que trataremos. Y de otra parte, toca a este tipo de religión -la local- pues nuestro caso trata de la religión de un pequeño territorio. Conjugando unas y otras posturas entremos pues, en el caso concreto de nuestro terreno, en el culto y su reapropiación significativa para los habitantes del sur de los Andes de Colombia y más concretamente del Macizo Colombiano. La reapropiación y articulación de santos y Vírgenes católicos en América Latina, no es un caso exclusivo del Macizo Colombiano. Como ya lo hemos dicho, todas las imágenes culturales (especialmente las de orden religioso) introducidas por los europeos en la América Indígena, fueron poco a poco y mediante un complejo proceso (de imposición y de asimilación), repensadas en los discursos y en las prácticas locales. Lo que intentaré mostrar y analizar aquí, es la manera como dicho proceso se ha concebido y asumido histórica y socialmente en esta región.

\section{El culto a los santos y a la Virgen en el Macizo Colombiano}

5 En los Andes sur colombianos la primera diócesis es fundada en el año de 1546, sin embargo, para nuestro caso específico El Macizo Colombiano, la evange-lización comienza hacia 1550 cuando los europeos entran en esta región. Como fué usual en todas las incursiones de los hispánicos en la América Indígena, todo conquistador venía acompañado por un cura doctrinero o misionero para la conquista de tierra firme. La incursión de los misioneros al Macizo Colombiano parece haberse dado en dos etapas: una hacia 1549 con los Agustinos principalmente, pero quienes se instalan de forma definitiva e infieren mayormente en la evangelización de esta región son los franciscanos ${ }^{5}$ . Estos misioneros como es sabido ya, se diferenciaron de las demás órdenes religiosas de la Conquista y la posterior Colonia (jesuítas, dominicanos, etc.) por su voluntad de adentrarse en la evangelización cristiana de los indígenas estudiando primero sus conductas normativas o normas sociales (costumbres), concepciones sobre la vida y el universo (creencias) y lenguajes, con la finalidad de lograr una evangelización cristiana más acorde con la manera de ser de los pueblos originarios ${ }^{6}$. Estos personajes fueron entonces quienes más consolidadamente llevaron las imágenes y representaciones católicas al mundo de los hoy indígenas y campesinos yanaconas del Macizo Colombiano, quienes desde una reapropiación cultural fueron construyendo su actual religión local.

6 El culto a las imágenes católicas en esta parte de los Andes tiene una jerarquía, que es concebida según la siguiente clasificación : "Santos Remanecidos" y "los otros santos". Es de aclarar que aunque la clasificación generaliza santos dentro de cada una de estas, se incluyen tanto los santos como diferentes acepciones de la Virgen. El primer grupo en cuestión es el más importante para los pobladores del Macizo Colombiano y desde luego 
para nuestro artículo y vale decir también, que algunos nativos llaman a estos santos "los renacientes". El término de Remanecido o remanecencialremanencia remite etimológicamente a "aparecer de nuevo o manifestarse alguna cosa al rayar el día. Persistencia de un fenómeno después de la desaparición de la causa que lo ha provocado ». (D.E.H.A., 1985, p. 2174).

7 Carmen Bernand (1985) en su trabajo sobre los Andes de Ecuador, se refiere al término renacientes, pero haciendo alusión a los mestizos, su trabajo consiste en analizar este concepto en relación con la dinámica social de la identidad. Sin embargo, las referencias que sus informadores hace sobre los renacientes, tratan sobre los primeros hermanos cuyos descendientes han sido domesticados, cristianizados y mezclados. En este sentido, se podría plantear que la clasificación de "Santos Remanecidos" del Macizo Colombiano hacen referencia a santos mestizos, santos que en la actualidad tal como sucede con los nativos, no son ni aborígenes, ni españoles, si analizamos el proceso de conformación social, aunque política y étnicamente sea evidente su adscripción como indígenas.

Localmente los "Santos Remanecidos" son presentados como "antiguas divinidades" que fueron adoradas por los antepasados (llamados "tapuncos"), y que en el momento de la Conquista se ocultaron bajo tierra huyendo de los españoles ${ }^{7}$. Estos remanecidos considerados como "antiguos dioses que adorabana los tapuncos" (antepasados) indican continuidad con un tiempo anterior (remanecer, aparecer de nuevo), con la época anterior a la Conquista. Estas divinidades son presentadas como los seres que conectan el mundo aborigen con el hispánico. Estos santos son imágenes de más o menos $50 \mathrm{~cm}$. de altura que según los discursos míticos han sido encontradas bajo tierra en sitios lejanos a los domesticados. Pero ¿cómo podría explicarse esta ubicación subterránea ?. En época de la Conquista cada conquistador llevaba de ser posible un misionero para bautizar territorios y cristianizar pobladores; en estos andares los misioneros abandonaban en apartados parajes pequeñas imágenes de santos y Vírgenes como un símbolo de cristianización. Esta forma de expandir el paisaje sagrado a través de iconos, permitía considerar colonizados sitios de difícil asentamiento colonial como la selva por ejemplo, accesible al conquistador sólo - para nuestro caso del Macizo Colombiano - hasta su pie de monte ${ }^{8}$, sitio hasta donde aparecen referenciados los hallazgos de pequeñas figuras que representaban santos y Vírgenes. Imágenes pequeñas de gran colorido y de rasgos faciales "aindiados", han servido como una prueba más en la sustentación de estos santos como propios, ya que el nativo encuentra un paricido entre estas características y las suyas, que efectivamente guardan cierta semejanza, afianzada aun más con los atuendos locales que en la actualidad les hacen llevar.

9 La representación de estos santos se asume a partir de las imágenes de diferentes acepciones de la Virgen como Virgen Mama Concia o Virgen de Caquiona (Municipio de Caquina), Virgen de los Remedios (Municipio de Bolívar), Virgen del Rosal (Municipio de Bolívar), Virgen Concepción de la Candelaria de Pancitará (Municipio de la Vega). Y de los santos San Sebastián (Municipio de San Sebastián), San Lorenzo (Municipio de Bolívar) y el Santo Santiago (Municipio de San Sebastián) (Ver mapa). De todos éstos sólo retomaremos algunos ejemplos. Estas imágenes están organizadas según una jerarquía y un rol cuyo criterio se basa en algunos casos en la descripción de la historia oficial católica, y en otros, sólo se tiene en cuenta el poder del remanecido legitimado socialmente a través de sus servicios milagrosos y/o la persona a quien el santo se le remaneció. Así, "Mama Concia" es la imagen más importante dentro de la categoría de los remanecidos, ya que ella «hizo remanencia» a María Quinayás, considerada según el mito como una 
«india de las antiguas». Es decir, como una india originaria del lugar, tomando su apellido indígena -Quinayás- como la prueba más rotunda del origen. Es importante señalar que esta « testigo de remanecencia » es la única que tiene en su honor una estatua -hecha en madera- y además, puesta dentro de la iglesia de la Virgen de Caquiona. Esta representación ha sido hecha (quizá de forma intencional) guardando efectivamente el fenotipo de las mujeres indígenas de la época colonial, descrita por algunos cronistas.

Le sigue en importancia San Sebastián, "santo milagroso mártir de la iglesia". La Virgen de los Remedios o "Virgen Tewa", " especialista en la sanación de enfermedades». San Lorenzo como "santo del fuego", por haber sido puesto sobre una parrilla en una hoguera como lo cuenta la historia católica. La última de la jerarquía pero no por ello sin importancia es la Virgen Concepción de la Candelaria de Pancitara.

11 Para algunos nativos, los "Santos Remanecidos" fueron desde siempre venerados por los «tapuncos» o antepasados, lo que demuestra la superposición de estas imágenes, que una vez reapropiadas en la cosmogonía indígena, se las articula efectivamente dentro del canon de las imágenes sagradas de la religión local. La ubicación de los antepasados junto a los remanecidos sirve a los nativos como prueba desde el discurso simbólico para sustentar que estos santos no fueron traídos por los españoles, sino que ya existían desde antes, y que al momento en que los antepasados se sepultaron bajo tierra huyendo de los españoles, los remanecidos también se ocultaron, pero que luego reaparecieron, "se remanecieron", tal como lo indican mediante discursos como :

Los tapuncos [o antepasados] rendían adoración a los "Santos Remanecidos". Con ellos estaban los santos y cuando los antepasados se hundieron, quedaron los remanecidos tapados, hasta que alguna persona los encontró y ya después vinieron los curas y les montaron el culto como está hoy ${ }^{10}$.

12 Existe una diferenciación total entre los "Santos Remanecidos" y los "otros santos", éstos son agrupados en : "santos aparecidos" y "santos hechizos". Los "santos aparecidos" son una categoría que remite a santos que surgen en la actualidad y que son considerados de menor importancia. Es decir, santos que « se le aparecen » a algún poblador, ya sea en una gruta, en los alrededores de una iglesia, etc. Los nativos plantean que estos santos hacen milagros igual que los remanecidos, pero que "no son vivos »; significando con este término, que no se pueden coger, transportar, que carecen de una imagen móvil. Los "santos hechizos" son todos los demás santos que del culto católico se tienen en las iglesias (por ejemplo san Pedro, san Juan, etc.). Estas imágenes son las únicas consideradas por los pobladores como españolas. Se refieren a estos santos como seres pertenecientes en su totalidad al imaginario católico español. Tanto los santos aparecidos como los hechizos, participan de un culto más desplazado o relegado en comparación con los remanecidos.

13 Por considerar que desde donde mejor se puede hacer el análisis propuesto para este artículo, es a través del contexto de los "Santos Remanecidos", retomaré en particular su rol de imágenes humanizadas como recuperadoras y congregadoras simbólicas del territorio social, cultural y ecológico de los campesinos y yanaconas habitantes de este territorio andino. Para tal fin me valdré en adelante de sus mitos y haré referencia a algunos ritos ${ }^{11}$ en particular. 


\section{Los Remanecidos fundando pueblos}

14 Hacia 1550 comienzan a llegar los primeros colonizadores ${ }^{12}$ que irán configurando el nuevo territorio del Macizo Colombiano. Pero ¿cómo se llevó a cabo este proceso ? La respuesta aparece inscrita en la memoria social de los yanaconas y campesinos, quienes a través de distintos mitos cosmogónicos plantean la fundación de sus pueblos y de cierta manera la dinámica de los mismos. Los distintos significados de dichos mitos y de las referencias de cronistas de la época, servirán de hilos conductores para abordar este apartado.

15 Al tratar el tema del poblamiento, al final de cada entrevista siempre surgían expresiones como : "son los santicos los que nos tienen aquí", "por ellos se fundaron estos poblados", "tiene que ir preguntando de los santicos y verá que allí esta como ésto llegó hasta aquí", etc. Ahondando en estas alusiones, pude observar cómo aquellos "santos fundadores de pueblos" a los que me hacían referencia, no eran santos cuales quiesa, eran los "Santos Remanecidos".

16 La fundación de los poblados a los que los nativos hacen referencia remite directamente a Pueblos de Indios del período de la Colonia entre 1559 y 1667, convertidos algunos posteriormente en Resguardos Indígenas ${ }^{13}$. En la actualidad no se reconoce a los españoles la creación de estos pueblos, puesto que los indígenas y campesinos han reescrito oralmente la historia de estas fundaciones a favor de su propia comunidad. Empleando la figura de ciertas imágenes católicas como reaparecidas, éstas se transforman en "Santos Remanecidos" que sirven como símbolo a los nativos actuales, para recobrar el poder de sus antepasados y ejercer el control sobre lo que podríamos llamar el nuevo amanecer de sus poblados.

17 Así pues, los nativos comienzan haciendo referencia a "los tiempos de antes", como la alusión a una historia constantemente recreada en el presente a través de los mitos de configuración de sus poblados. La memoria sobre estos mitos ha permitido reconstruir el pasado, presentando su historia redefinida y reevaluada. Es decir, muchos de los aspectos dispersos (como los cultos, la organización nativa, sus ubicaciones originarias, etc.), que ha dejado la historia de la Conquista, se han reunificado a través de las memorias colectivas de los mitos de fundación de los poblados del Macizo Colombiano. Los relatos de estas fundaciones no tratan sobre el origen de la tierra y de los pobladores, son narraciones que a través de los mitos de surgimiento de sus "Santos Remanecidos", representan la fundación de los pueblos que se reubicaron a través de la figura de Pueblos de Indios en la época colonial. Son mitos donde se excluye a los europeos como fundadores de los pueblos, y se presenta como tales a los nativos, quienes por medio de la figura de los "Santos Remanecidos" como divinidades propias, se reconocen como constructores legítimos de sus asentamientos.

18 La referencia que se presenta en principio de una manera inconsciente, es decir, que sólo se hace alusión al mito como parte de la historia local, se va convirtiendo en colectivo, en una puesta en escena de la discusión sobre quiénes son los gestores directos de un proceso social propio. Pasar de un patrón de poblamiento disperso como lo dice un Visitador de la época: «Viven los naturales en bohíos de paja y muy apartados unos de otros $(. . .)^{14}$ ", a la organización forzada en Pueblos de Indios según las costumbres y leyes de la España medieval, es lo que pone en marcha lo que he llamado la reescritura oral de una propia historia. Desde el punto de vista de la historia oficial española de la Colonia, el 
acto de fundación legítimo de un pueblo, era el bautizo territorial por parte del cura misionero. Este bautizo que como ya se señaló anteriormente comienza en 1559 y va hasta 1567, se hacía efectivo cuando el misionero levantaba la cruz, ordenaba construir un templete que serviría de iglesia y ponía un nombre compuesto, mitad indígena y mitad católico al nuevo poblado (Santiago del Pongo, por ejemplo). Una vez establecidos los distintos Pueblos de Indios, las autoridades coloniales pretendieron asimilarlos y desarticularlos entre sí, intención que no tuvo éxito, pues se mantuvo entre ellos las alianzas familiares y afinidades culturales como el idioma (básicamente el quechua) y algunos nexos políticos.

19 Ante todas estas disposiciones de las autoridades coloniales, los indígenas se sublevan y con resistencia asumieron finalmente esta forma de asentamiento, pero dándole una nueva significación. Las plazas y atrios de las iglesias se convirtieron en lugares donde se recreaban las formas antiguas con las venideras, en una reconstrucción espacial tapiz de lo que sería en adelante la cultura local.

20 Frente a esta historia de fundación y asentamiento oficial de los Pueblos de Indios, está el relato del mito que sirve como mecanismo a través del cual la memoria colectiva refunda estos pueblos. Los pobladores del Macizo Colombiano no recuerdan la historia de la Conquista y la Colonia, por más que se imparta en las escuelas de educación pública. Esta historia no ha llegado a ser significativa para ellos, porque para los efectos socio-políticos buscados en esta legitimación, no es sobre la historia aprendida, es sobre la historia vivida (sentida como suya) donde se apoya su memoria.

21 Una de las principales funciones de los remanecidos en los mitos que los presentan, es la de instaurar el orden social en un espacio que inicialmente se concibe como salvaje. Al respecto de los escenarios e imágenes desde donde cobran vida los referidos mitos, es importante señalar que narraciones similares se encuentran en muchos pueblos de Europa, especialmente para nuestro punto de referencia en España. William Christian (1990) nos describe mitos de lo que él llama "hallazgos de santos", con una estructura similar a la de los "Santos Remanecidos" del Macizo Colombiano: "A través de la mediación de animales domésticos (...) un vaquero o pastor es alertado de la presencia de una imagen en un paraje agreste : bajo tierra o en una cueva, en un árbol $u$ otra planta silvestre o en una fuente. El vaquero o pastor, o el cura y los lugareños intentan llevar la imagen a la iglesia parroquial, pero aquella regresa por si sola a su oculto emplazamiento, y al final se levanta una capilla en ese paraje » $(1990$, p. 32).

22 La similitud en el patrón seguido entre las narraciones europeas y nuestro caso es apenas comprensible, si consideramos que fueron narraciones transmitidas en la Evangelización de las Indias. No obstante, estos relatos fueron reapropiados local-mente en forma de mitos que en la actualidad no se expresan como meras tradiciones (se dice que..., se cuenta que...), sino que por el contrario, se asumen directamente personificando el encuentro entre la imagen y el nativo ( «ue Maria Quinayás que la encontró »), e intentando ubicar al "Santo Remanecido" en un tiempo (" eso haría como unos 20 siglos ») aunque no corresponda a una cronología real. La personificación y la alusión cronológica son otro signo más de cómo hacen suya la imagen, haciendo los esfuerzos necesarios en la narración para presentarla bajo un origen local.

23 Para sustentar este planteamiento veamos a continuación algunos de los mitos más importantes. "Mama Concia" por ejemplo, se remanece en la montaña sobre una laguna : 
A Mama Concia la habían encontrado haría unos 20 siglos (...),cuando por aquí no había habitación (...). Esto ha sido montaña salvaje, lagunas salvajes, no era como hoy.

La alusión a los "20 siglos" quizá sugiera la ubicación del tiempo lejano en que se sitúa la Conquista. Seguidamente las frases, "Cuando por aquí no había habitación...Esto ha sido montaña salvaje, lagunas salvajes no era como hoy", pueden servir para señalar la invasión de la Conquista en todo el territorio del Macizo, dándole a éste diferentes usos según fuera la necesidad de las lógicas del asentamiento español. Muchos son los relatos que aluden a la desmesurada incursión de la Conquista, con al ánimo de extender los poblados y facilitar los trabajos propios de las Encomiendas. Sin ningunas condiciones humanas, crearon los pueblos de mitayos ${ }^{15}$ indígenas en las minas aledañas a cerros y montañas, para concentrar la población junto a los lugares de producción. Continuando con el mismo mito tenemos :

Quien la encontró fue una india de las antiguas, la vieja india Quinayás, una lavandera (...). Cuando ella la encontró se fue secando el agua, había sido como si el agua se hundiera por debajo de la tierra. La india cogió a la Virgen y notó que estaba liviana, pues quería que la Quinayás se la llevara(...). Esta la ponía en la cabecera de la cama, al otro día la Virgen se marchaba, se salía en la noche ! y que en la tarde venía la india Quinayás y la Virgen había vuelto, había llegado con las enaguas llenas de barro! (...). La vieja se cansó de llevarla a su casa, porque siempre se marchaba la Virgen, así que una vez la Remanecida le había dicho que ella, allá en esa casa no se acostumbraba y que si no la dejaba donde ella quería haría caer grandes tormentas eléctricas. La india hizo hacer con la comunidad un ranchito de paja al pie de la laguna y el agua de esa laguna se secó poco a poco y la Virgen quedó parada en un tronco de un árbol. A partir de ese momento la comunidad ya había contado a todos los españoles, a la otra gente y a los curas. (...) Entonces la comunidad le había hecho capilla de paja y fue derrumbando montaña. A ella de allí nadie la movió y tuvieron que hacerle capilla encima de la laguna ${ }^{16}$.

La tercera imagen: "la encontró fue la vieja india Quinayás", presenta la legitimación de los indígenas como verdaderos poseedores de los remanecidos, se excluye al conquistador y se establece el vínculo más cercana entre el santo y la comunidad. El párrafo : « La india hizo hacer con la comunidad un ranchito de paja al pie de la laguna y el agua de esa laguna se secó y la Virgen quedó parada en un tronco... A partir de ese momento la comunidad ya había contado a los españoles y a los curas ", sugiere a través de las frases subrayadas, la autonomía de fundación de un pueblo entre la "Mama Concia" y la comunidad de Caquiona (lugar de origen de esta Virgen), intencionalidad última del mito. Pero además, la frase: "contado...a la otra gente", vincula al santo con las nuevas generaciones depositarias de esta "antigua divinidad", como ofrecimiento de los antepasados, quienes posibilitan el reencuentro entre "la otra gente" (nuevas generaciones) y "Mama Concia".

En cuanto a la movilidad figurada dada a la Virgen en el mito, sirve como pretexto para mostrar los movimientos coloniales a los que se vieron abocados los nativos por la instauración de los Pueblos de Indios y las Encomiendas, y la posesión definitiva de un territorio a través de la metáfora de "construcción de la capilla" con techo de paja como la casa de un aborigen: "le habían hecho capilla de paja". Pues tal como hemos visto antes, con este acto se oficializaba colonial-mente la instauración de un pueblo, de modo que los indígenas conservan el mismo símbolo en el mito, pero le confieren un significado propio. 
27 Así como a "Mama Concia" se la relaciona directamente con una lavandera, a través de la cual cobra vida la imagen de esta Virgen, la Virgen de los Remedios y San Sebastián se comunican con los nativos empleando la mediación de los cazadores. En el mito de este remanecido son estos actores quienes comunicándose con él, posibilitan la refundación del poblado de San Sebastián. En el relato, estos personajes median entre el antes y el después de la congregación del pueblo: entre un espacio "bravo" y otro "amansado". En este sentido con respecto al mito de San Sebastián cuentan que :

Antiguamente habían unos cazadores que estaban cazando por aquí que antes era montaña salvaje. Entonces cuando estaban caminando de pronto se encontraron a San Sebastián atado a un tronco, lo sacaron y se lo llevaron para una casa arriba en el Alto [alto ?] y allí lo pusieron. Al día siguiente fueron a visitarlo y no estaba, entonces salieron a buscarlo en el lugar donde lo habían encontrado los cazadores y allí estaba en ese monte. El remanecido San Sebastián les dijo entonces que si lo querían a él le hicieran la casa ahí donde lo habían hallado, donde estaba remanecido. $\mathrm{Y}$ ahí le hicieron la casa, la capilla, y después de eso se comenzó a crear el pueblito allí. Así se fundó el pueblo de San Sebastián. Al santo se lo han querido llevar para otras tierras pero el santo remanecido no se puede llevar a otros lados, se queda donde se remanece $(. . .)^{17}$.

Al indagar entre los entrevistados si cuando se referían al Alto, lo hacían pensando en un lugar llamado así en San Sebastián -y que efectivamente está a una altura un tanto superior del poblado de San Sebastián-, o si estaban indicando con ello un sitio geográficamente más alto, se dieron diferentes respuestas contradictorias entre sí. Revisando más tarde datos de archivo encontré que el pueblo de San Sebastián había sido fundado como Pueblo de Indios en el actual poblado de El Rosal (ver mapa), que está a una altura aproximada de 3000 metros (en el año de 1560); siendo cambiado luego a tierras más bajas con 2400 metros (hacia mediados de 1800) donde se localiza en la actualidad. Este cambio aparece justificado en las actas de fundación, como la única solución que pudo darse a los constantes conflictos que había entre las autoridades que administraban el pueblo y los pobladores ${ }^{18} \mathrm{Si}$ tomamos la frase completa que incluye a la palabra Alto en el mito, tenemos : "se lo llevaron para una casa arriba en el Alto [alto ?]". Retomando la información del archivo y la alusión a un lugar más alto que San Sebastián, donde se pretendió situar al pueblo y que debido al enfado del santo se situó en un territorio más bajo, es decir donde está ahora, efectivamente el mito sobre este remanecido, está igualmente haciendo referencia a cambios de asentamiento poblacional, producto de los acomodamientos coloniales.

Por su parte San Lorenzo surge en el mito, como quien media directamente entre la institución clerical que tiene el dominio de fundación de los pueblos, y los nativos que se revelan ante tal imposición. Pero esta mediación en el relato no es conciliadora, por el contrario, es una protesta frente al estamento clerical ; el santo reivindica el derecho de la gente a elegir su sitio de habitación, y personaliza en el texto del mito la sublevación de los pobladores, tal como lo ilustra el siguiente párrafo :

A San Lorenzo lo encontraron unos leñadores (...). Vinieron y lo comentaron y fue a verlo mucha gente y luego le avisaron al cura (...). Entonces ese cura se lo llevó y cuando se levantó al día siguiente el santo no estaba se había marchado a la capilla donde había sido puesto en principio por la gente. El cura lo volvió a coger y el remanecido se devolvió nuevamente. Cuando el cura pretendió ir a poner el santo nuevamente, se le reveló y le dijo : “cura si me mueves te prendo fuego". Así el cura ya decidió venir a celebrarle misa a donde San Lorenzo se había remanecido y no pretendió llevárselo más, le hicieron el templo y allí fundaron el pueblo de San Lorenzo. Por eso es que no creemos que sean los españoles quienes lo trajeron, 
porque si fuera así, no hubiese sido tan severo con el cura como se cuenta y además es un santo demasiado milagroso. ${ }^{19}$

30 No puede decirse que San Lorenzo como tal hubiese sido un Pueblo de Indios, sin embargo, las tierras de este actual pueblo eran en la Colonia otro de los asentamientos de mitayos, debido a las minas de oro que había a su alrededor. Así que la historia de fundación de este poblado, atravesó por similares vicisitudes a las de los Pueblos de Indios propiamente dichos. De ahí que también existan datos (aparte del mito) sobre su fundación, que nos muestra igual cambio que en los anteriores. La fundación del poblado de San Lorenzo, también tuvo dos etapas. La primera se efectuó en el sitio llamado La Loma, donde permaneció desde 1780 hasta 1855, época en que debido a la precariedad del terreno donde fue fundado, los antiguos nativos se sublevan y cambian el sitio de habitación, debido a los deslizamientos de tierra, los múltiples incendios forestales y la escasez de agua en el lugar. Por tal motivo, hacia 1856 deciden trasladar el poblado al lugar donde hoy permanece, quedando la antigua fundación como Pueblo Viejo ${ }^{20}$.

31 El mito de La Virgen Purificación de la Candelaria, guarda relación con los otros relatos en los espacios y actitudes de la remanencia (agua, monte, los movimientos, etc.), sin embargo, esta Virgen al contrario de los restantes remanecidos, aparece bajo la figura de pacto, es decir, no se enfada, ni amenaza con grandes represalias, aunque sí pone de manifiesto el marcharse si la mueven. Ésta ayuda directamente a allanar el camino de la fundación : “(...)Ella les dio permiso y separó el agua de la tierra y quedó hecho el camino (...) para seguir fundando el pueblo de Pancitará”. De esta manera cada santo es representado con un papel y una actitud en esa reapropiación de la historia de fundación de los Pueblos de Indios.

El modo como se recrea la historia en los mitos, pone de manifiesto cómo la memoria se presenta en un proceso total de mensajes reificados en los discursos sociales, que bien podríamos llamar una reescritura de esta historia. La compaginación del mito con las referencias coloniales, sustenta la fundación cultural, la legitimación local de la forma, el contexto y el tiempo, en que se establecen los actuales pueblos del Macizo Colombiano. En este orden de ideas, la remanencia de los santos congrega simbólicamente a las poblaciones dispersas tal y como se asentaban a la llegada de los europeos. No se acepta al misionero español que poniendo la cruz bautizaba al pueblo e instauraba el orden colonial, son las antiguas divinidades quienes instauran el nuevo orden y convierten así los territorios ecológicamente salvajes, en espacios domesticados social y ecológicamente.

Las referencias a los movimientos de los santos (el santo que sube y que baja) ilustra sobre dos aspectos. Primero acerca del carácter que se le imprime a los remanecidos como santos vivos en el sentido literal del término: hablan, se enfadan, pactan, habitan, humanizan, etc. Pero además, el movimiento del santo invita a pensar en el proceso de reacomodo o cambio socio-cultural que se produjo en los nuevos asentamientos de los nativos con la creación de los Pueblos de Indios, tanto dentro de la nueva organización social ("vivir en policía") como de la religión local (cultos propios y venideros a través de iconos introducidos).

Los pasajes de los mitos donde el santo se enfadaba si no lo dejaban donde quería, y lanzaba fuego y castigos sobre los transgresores del orden, puede estarnos mostrando cómo se corrige la historia oficial en la memoria del mito; no es el español quien dictamina el orden, son sus dioses, quienes aparecen como portadores de un poder adquirido mediante la nueva simbología con la que los indígenas los dotan. 
Podemos decir finalmente que los mitos de los remanecidos no sólo son un recurso mnemotécnico, son también un recurso social vivenciado y empleado a través de metáforas que explican y recrean, el contenido, el espacio y el tiempo de la historia local. Por medio de estos mitos, los nativos actualizan el pasado en el presente reflejándolo en la puesta en escena de la memoria colectiva, mediante el discurso explícito del mito y el simbolismo de las prácticas sociales. Así entonces, los remanecidos no sólo han sido domesticadores aborígenes en el repoblamiento de tierras de la Colonia, sino que también son empleados actualmente en la reapropiación cíclica que los comuneros hacen del territorio, bajo distintos rituales que se llevan a cabo durante todo el año y que son conocidos como las "alumbranzas" o recorridos comunales del santo en procesiones y las fiestas de los "Santos Remanecidos" que constituyen espacios sociales donde el santo reapropia año tras año el espacio territorial para los pobladores, como un recordatorio de una historia ganada para sí mismos. A través de estos ritos los nativos viven su espacio territorial, es decir, lo vuelven suyo, lo transportan y sostienen del pasado en la memoria incorporada ${ }^{21}$, puesta en escena en un presente cíclicamente teatralizado mediante los citados ritos.

\section{Los remanecidos en las prácticas sociales de la actualidad}

\section{En tiempo de alumbranzas}

Este ritual también es llamado la "correría del santo" por tratarse fundamentalmente del recorrido que el santo hace a través de todo el territorio habitado. La "correría" comienza uno o dos días después de la fiesta de los "Santos Remanecidos", así en cada resguardo o municipio habrá "alumbranzas" durante todo el año, ya que dichas fiestas van de enero a septiembre. Esta práctica consiste en llevar al remanecido de vereda en vereda ${ }^{22}$, según el orden de petición que éstas tengan, para celebrarle la "fiesta chiquita" durante toda una noche. Una vez seleccionada la casa donde se hará el rito, todos los comuneros acuden a engalanarla con flores, velas y cintas de colores, el lugar donde se pondrá al santo debe estar especialmente arreglado. Cuando el remanecido sale a la "alumbranza", en la iglesia permanece una copia de estos santos, de esta manera convierten al santo en un protector omnipresente.

En las "alumbranzas" los comuneros intercambian a los remanecidos entre sus poblados, éstos se visitan a través del santo. La visita de los santos fuera de sus lugares de origen se hace dependiendo de las peticiones. Y en algunos casos siguen la jerarquía o el rol de cada uno.

"Mama Concia", por ser la "Virgen India", es invitada siempre como Virgen principal, a la cual se acude sin mayor motivo y al mismo tiempo por motivos muy importantes. San Lorenzo como santo del fuego es llevado en "correría" especialmente en la época de preparación del terreno para la siembra, donde precisamente se hace la tumba, roza y quema. San Sebastián por ser el santo mártir se acude a él en momentos de conflictos. La Virgen de los Remedios, o "Virgen Tewa", es la Virgen a la que se visita buscando la sanación de los males físicos. En cuanto a la Virgen Concepción de la Candelaria de Pancitará, no encontré de forma general un rol específico, aunque es una Virgen muy importante entre los remanecidos como ya lo hemos visto. Las alumbranzas en cuanto a su 
papel social de congregación son en muchas oportunidades espacios de reconciliación entre veredas o diferentes poblados que, por determinadas razones, han entrado en discordia. A este respecto algunos narradores me hacían referencia, a que al santo no sólo se le hace una alumbranza para festejarlo, sino también como pretexto para hacer las paces entre pueblos vecinos. Es importante destacar que este tipo de alusiones no las hacen los personajes importantes de las comunidades (líderes políticos, síndico de la iglesia, etc.), sino gente del común, ya que al hacer la pregunta del por qué de las alumbranzas especialmente a los síndicos, estos contestaban con respuestas como:

Las alumbranzas son para festejar al santo, para reunirnos y a veces para reconciliar a las Vírgenes que como todas las mujeres se pelean (...). Los santos pelean entre ellos como nosotros. Para devolverse la amistad entonces se visitan en tiempo de alumbranzas, de esta manera todo se soluciona. ${ }^{23}$

Ante los conflictos entre las comunidades primero hablan los santos y después intervienen los estamentos políticos. Frente a un conflicto evidente en muchos casos lo primero que se hace es convocar una alumbranza. Una vez hecha ésta, se esperan los efectos logrados en los concurrentes y el desenvolvimiento de la misma, para proceder a convocar asambleas y discutir los problemas. Si el remanecido está ya pedido para una alumbranza, se habla con los encargados y se les pide el favor de ceder el santo. He de decir que esta práctica no siempre es efectiva y los conflictos entonces, han de solucionarse buscando otras alternativas ; pero algo sin duda evidente es que los pobladores sin cargos políticos, los comunes, disfrutan y se reconcilian entre si. De este modo el recorrido del santo y la ceremonia, conjunto de la alumbranza, cumplen las finalidades sociales de congregar, reapro-piar y reconciliar el territorio y su gente, que luego de este rito vuelve a sus vecindades y a atravesar los lugares temporalmente restringidos a causa de los conflictos.

\section{Las fiestas de los Remanecidos}

Las fiestas de los "Santos Remanecidos" son muy semejantes a las fiestas de los Santos Patronos del mundo católico. Sin embargo, existen algunos elementos que como veremos más adelante nos establecen la diferencia con la religión local. Aunque cada fiesta tiene un día en el calendario ritual, realmente son 9 días de la novena ${ }^{24}$ y dos o tres días de la celebración misma. La organización y control total de la fiesta está a cargo de la Junta de la Fiesta del Remanecido, compuesta principalmente por el Cabildo Indígena y La Junta de Acción Comunal ${ }^{25}$. Los actos centrales de las fiestas son: la "reliquia", la "acción de gracias", la "romería", las "verbenas", las "chirimías" (grupos de música autóctona), las "bandas de música" y los "castillos de fuego". Estos actos tienen lugar ya sea dentro o fuera de la misa y de la procesión y buscan principalmente mostrar el poder y adscripción del santo como una imagen sagrada de origen local y reiterar además, entre los nativos y ante los extranjeros -que acuden a la fiesta-, la identidad como indígenas yanaconas y campesinos del Macizo Colombiano. El "castillo de fuego" y la "acción de gracias" son consideradas representaciones directas del poder de los santos. El santo es colocado en el castillo como un símbolo de poder que todo lo puede, aunque generalmente sepan que esta puesto de tal forma que las llamas no pueden tocarlo. Cuando el castillo arde todos gritan frases como: - « Tú que todo lo puedes, sálvate », -« Santico remanecido líbranos del mal», -«Tú poderoso de lo alto danos buena cosecha», etc. Estas aclamaciones sugieren que un "Santo Remanecido" es tan poderoso que ni las llamas pueden contra él. "La acción de gracias" objetiviza el poder del santo ya no sobre la colectividad, sino sobre el individuo. Esta acción, consiste en dar ofrendas en dinero o en especie y en poner 
placas con frases alusivas al favor recibido a título individual : -"Porque tú me diste lo que tanto te pedí (...), -" Acción de gracias te damos oh San Sebastián por tus milagros : tus devotos hijos, Familia X". -"Gracias santo por haberme devuelto mi oído (...)", etc. Estas prácticas del gesto individual, socializan las facultades del santo que se construyen en el discurso cultural.

Los "castillos de fuego", las "romerías", "la reliquia", "la acción de gracias", los bailes, la "chirimía" y las bandas de música, además, reconstruyen paso a paso el recorrido cotidiano de los comuneros. Los espacios que se delimitan con la ocupación en la fiesta (músicos, vendedores, feligreses, etc.) y que son recorridos por el santo en las procesiones, limpian y curan el territorio para la comunidad: el santo imparte con su andar hecho ritual, protección simbólica para los nativos. Además de esta protección se logra un efecto político de reapropiación territorial. Los nativos legitiman en las fiestas la autoridad del Cabildo Indígena y de la Junta de Acción Comunal, frente al Ayuntamiento Municipal. Con el control total de la fiesta estas entidades, reapropian el resguardo y territorio campesino para los suyos. Ante el poder central del Ayuntamiento que detenta la propiedad de un territorio absoluto con un poder igualmente absoluto, los indígenas y campesinos recrean el territorio urbano como posibilidad comunal y supracomunal; dando cabida a propios y extraños, quienes a través de la fiesta viven en espacios grupales y colectivos, los actuales Pueblos de Indios ${ }^{26}$ en honor a los remanecidos.

Finalmente he de decir que hasta mediados de la década de 1980, los comuneros recuerdan que a estas fiestas era un honor asistir y el participar directamente en ellas era un acto de identidad natural del hombre maciceño. Sin embargo, debido a los cambios ocurridos a raíz de la incursión de los cultivos ilícitos de la coca y la amapola, todos estos intereses identitarios considerados naturales, fueron decayendo entre la población joven principalmente, quienes no veían en ellas más que un sitio de mera diversión. A pesar de ello, estas celebraciones se esfuerzan día a día por mantener su papel central en torno a la identidad de los nativos y del santo, gracias al esfuerzo de las otras generaciones. Los ancianos especialmente, son quienes han tomado como suya la batalla de reavivar el culto del remanecido en la fiesta, como uno de los más importantes soportes de la memoria local que los ha acogido como santos de origen propio. En la actualidad, durante las fiestas es donde los mitos de estos santos están verdaderamente en la boca de todos, no solamente porque la práctica misma (la fiesta) recuerda el sentido (festejar un santo local), sino también por el énfasis que ha puesto la gente de mayor edad en recordar para mantener. Desde el primer día de la novena las personas mayores cuentan en horas de casa es decir, en horas de las comidas, las narraciones de origen del santo, invitando a los jóvenes a venerarlo en su fiesta. Este mecanismo de aprovechar los acontecimientos para volver a la memoria, permite recobrar la vigencia del mito ("Santos Remanecidos"/fundación de pueblos)y rememorar la historia rees-crita comunalmente ("Santos Remanecidos"/ alumbranzas-fiestas).

\section{Para la discusión final}

El registro y manejo de los mitos sobre los santos definidos como remanecidos (reaparecidos) y asumidos como "antiguas divinidades no católicas", han servido para ubicar y volver propia la identidad histórica de los indígenas y campesinos yanaconas del Macizo Colombiano. Los discursos comunales en la construcción y la reproducción de la memoria en las narraciones, podríamos ubicarlos en dos niveles de conciencia distintos: 
uno a nivel político, capaz de modificar y reordenar los acontecimientos históricos en una especie de bricoiage, en función de los objetivos de las estrategias políticas buscadas (reconocerse como verdaderos fundadores y constructores de sus pueblos); el otro relacionado con los mecanismos de la memoria colectiva, desde donde se muestra una reconstrucción totalmente ficticia de los acontecimientos, recortando el pasado y operando censuras sobre los elementos de ese pasado que se desearía consignar al olvido (santos que regresan -se remanecen-y en nombre de los antepasados les devuelven la legitimidad histórica y social). Así, el discurso cultural es manejado al mismo tiempo como principio estructurante y modalidad representativa de la realidad.

Los ritos como el otro nivel de representación de la práctica social, permiten dar vigencia y continuidad cíclica a aquella reapropiación y articulación de los "Santos Remanecidos" en la vida cotidiana (el santo articulado al diario vivir de la comunidad) e institucionalizada ( alumbranzas y fiestas) de los nativos.

Así, mito y rito han sido los escenarios desde los cuales la etnografía ha "hablado", permitiéndonos observar y analizar el uso y simbología particular que los pobladores de esta parte de los Andes, han dado a las imágenes católicas introducidas hacia el siglo XVI, cuyo objetivo de ser el eje central por medio del cual el aborigen entraba en la "vida civilizada", muy pronto se convirtió en una de las formas metafóricas (en discurso y práctica) más eficaces para socializar una historia que volvieron suya, utilizando las mismas herramientas de la colonización. De esta manera, asistimos a un espacio de encuentros (o desencuentros?) en donde el colonizado aparentemente acepta las imposiciones del colonizador, empleando sus mismas armas ideológicas para reinventar y reescribir lo que se considera propio.

\section{BIBLIOGRAFÍA}

BERNAND Carmen, La solitude des Renaissants. Malheur et sorcellerie dans les Andes, Paris, Presses de la Renaissance, 1985.

BUENAHORA Durán, Gonzalo, «Los Pueblos de Indios del Macizo Colombiano durante el periodo colonial », en Memorias del seminario de Etnohistoria del sur de Colombia y norte del Ecuador, PopayánColombia, Universidad del cauca, 1994.

BOUYSSE-CASSAGNE Thérèse, « De Empédocles a Tunupa : Evangelización, Hagiografía y mitos », en Saberes y Memorias en los Andes, Paris-Lima, Instituí des Hautes Études de l'Amérique Latine Institut Français d'Études Andines, 1997.

BOUYSSE-CASSAGne Thérése, Lluvias y Cenizas, dos Pachacuti en la historia, La Paz, Hisbol, 1988.

CIEZA DE LEON Pedro, Cronica del Perú, Segunda parte, segunda edicin corregida, Lima, Pontificia Universidad Católica del Perú, 1986.

CÁTEDRA T. María, «L'invention d'un saint, symbolisme et pouvoir en Castille », en Revue Terrain n $^{\circ}$ 24, 1995, pp. 15-32. 
CERON Patricia, El puma y la india de punturco. Popayán-Colombia Tesis, Antropología Universidad del Cauca, 1990.

CONNERTON Paul, How Societies Remember, Cambridge, Cambridge University Press, 1989.

CHRISTIAN William A., Apariciones en castilla y Cataluña (Siglos XIV-XVI), Madrid, Editorial Nerea, 1990.

CHRISTIAN William A., Religiosidad local en la España de Felipe II, Madrid, Editorial Nerea, 1991.

GISBERT T., Iconografía y Mitos indígenas en el Arte. La Paz, Gisbert Edición, 1990.

HALBWACHS Maurice, La mémoire collective, Paris, Presses Universitaires de France, 1950.

LÓPEZ Claudia Leonor, Los Caquiona : Fríanos de sangre caliente. Tesis pregrado, Popayán-Colombia, Universidad del Cauca, 1991.

LLANOS Vargas Hector, Los cacicazgos de Popayán a la llegada de losconquistadore, Bogotá, Fundación de Investigaciones Arqueológicas Nacionales Banco de la República, 1981.

NATES CRUZ Beatriz, "Lo bravo, el amanse y lo manso" : apropiación, representación y dinámica social del territorio andino (Macizo Colombiano), Madrid, Universidad Complutense de Madrid, 1997.

PACHÓN Ximena C, « Los pueblos y los cabildos indígenas : la hispanización de las culturas americanas ", en Revista colombiana de Antropología Volumen XXIII, Bogotá, Instituto Colombiano de Cultura, 1980-1981.

TOVAR Pinzón, Hermes, No hay caciques ni señore, Barcelona, Editorial Sendai, 1988.

URBANO H., En nombre del Dios Wiracocha, Cusco, Allpanchis, 1988.

VASQUEZ Carvajal William, Relaciones territoriales vistas desde él historial de la población de San Juan, Tesis de Antropología, Popayán-Colombia, Universidad del Cauca, 1989.

VV.VV (varios autores). Diccionario Enciclopédico Hisp áno-Americano, Tomo VIII, 1947.

WACHTEL N., Le retour des Ancêtres, Paris, Gallimard, 1990.

Archivos consultados

Archivo Municipal, San Sebastián (AM/SB) 1560. Actas de Fundación.

Archivo Corregimental, San Lorenzo (AC/SL) 1780. Actas de Fundación.

\section{NOTAS}

1. Este artículo forma parte de mi tesis doctoral: «Lo bravo, el amanse y lo manso»: apropiación, representación y dinámica social del territorio andino (Macizo Colombiano), Universidad Complutense de Madrid-Dic, 1997.

2. Las letras en itálica las empleo a través de todo el texto para resaltar algún término o idea al lector, y las comillas las uso para citar a los nativos o autores bibliográficos.

3. Los nombro por separado (campesinos e indígenas yanaconas) no por que identitariamente sean dos grupos aislados, sino por que después de la década de 1980, algunos decidieron adscribirse al sistema de autoridades indígenas y recuperar el poder sobre sus tierras comunales (llamadas Resguardos), mientras otros tomaron la decisión de seguirse denominando campesinos, pues según ellos volver sobre la denominación indígena (con "bautizo" étnico y todo) era entregar el poder sobre sus tierras de propiedad privada y regresar al pasado. 
4. Por considerar que el concepto de sincretismo es tan difuso y tan general que apunta a todo y a nada en particular. Este concepto a mi manera de ver suprime en gran medida el mirar « estos encuentros » como procesos.

5. BUENAHORA Gonzalo, 1994.

6. Aunque las generaciones posteriores de franciscanos que llegaron a América no se mostraron a favor de dicho método de evangelización y prefirieron evangelizar a través de la hispanización de las culturas autóctonas, algunos de estos misioneros la siguieron practicando hasta muy avanzado el periodo de la Colonia.

7. Debo decir que en la actualidad los sacerdotes católicos hacen grandes esfuerzos por hacer entender a la gente local, que dichas imágenes son santos católicos. Los discursos entorno a esta cuestión se trabajan más en la época de la fiesta del remanecido, sin embargo, el culto de la religión local de campesinos e indígenas yanaconas se mantiene y difunde a través de sus mitos y ritos.

8. BUENAHORA Durán, 1994.

9. Tewa es el nombre que recibe el médico de la medicina indígena o rural y significa " hombre que conoce de males".

10. Entrevista trabajo de campo, 1996.

11. El mito en este trabajo debe ser entendido como un conocimiento que se "vive", ya en la socialización de su propia narración, ya en su corpus ideológico que inspira diversas explicaciones y prácticas sociales, en la cultura que lo asume como suyo. Y el ritual como las acciones que tienen en común poner fuera del tiempo de la cotidianidad momentos recurrentes para poder reflexionar sobre el orden social y con las que los actores recrean y comunican, ciertas premisas básicas sobre las cuales se basa su vida social - colectiva - y particular individual -.

12. Desde luego colonizaciones forzadas y voluntarias: españoles, negros esclavos (para el trabajo de las minas de oro) y otras poblaciones indígenas, especialmente del Perú y Ecuador.

13. Los Pueblos de Indios fueron una organización sociopolítica de la población autóctona concentrada en torno a las Encomiendas instituciones que a su vez fueron creadas para facilitar el cobro de tributos de la población indígena. Y los Resguardos Indígenas son una entidad territorial actual, donde la propiedad sobre el territorio es comunal y la autoridad es regida por un Cabildo Indígena que opera bajo leyes internas consuetudinarias reconocidas por la Constitución Colombiana.

14. Visitador anónimo. Referencia tomada de la transcripción de Visitas hechas por Hermes Pinzón TOVAR, 1988, pp. 32-33.

15. Los mitayos eran los indígenas que vivían en las mitas. La mita era un sistema de reclutamiento de indígenas para el trabajo en las minas de oro especialmente.

16. Mito recogido por Claudia LóPEZ en Caquiona, 1991.

17. Entrevista hecha en trabajo de campo, 1996.

18. Sala de Archivo Municipal, Actas de Fundación. San Sebastián, 1994.

19. Entrevista hecha en trabajo de campo, 1994.

20. Sala de Archivo Corregimental, Actas de Fundación, San Lorenzo, 1994.

21. En el sentido de CONNERTON, 1989.

22. Vereda es la sección administrativa y territorial mas pequeña de un municipio.

23. Entrevista hecha en trabajo de campo, 1996.

24. La novena consiste en hacer durante 9 noches la lectura de la historia católica del santo o Virgen y rezar un rosario. Después del " rezo de la novena », los nativos se reencuentran en el atrio de la iglesia alrededor de actos de esparcimientos de corta duración como juegos, danzas, etc.

25. Máximas autoridades que representan a los indígenas y a los campesinos.

26. No en el sentido colonial, sino en el sentido de que son poblados habitados por indígenas. 


\section{RESÚMENES}

Este artículo pretende analizar el proceso mediante el cual se ha concebido y asumido histórica y socialmente la articulación y reapropiación de santos y Vírgenes católicos en los Andes del sur de Colombia. Dentro del marco de la religión local, se recorren los mitos y los ritos dentro de los cuales estas imágenes, introducidas en el siglo XVI, han sido empleadas por la población autóctona como una de las formas metafóricas más eficáces para socializar una historia que volvieron suya, reinven-tando estos hoy cultos andinos pero cristianos también.

Cet article analyse les processus d'articulation et d'appropriation socio-culturels des Vierges et des saints catholiques dans les Andes du sud de la Colombie. Situé dans le cadre de la religion locale, il montre, en se fondant sur l'étude des mythes et des rites qui entourent ces images, introduites au $\mathrm{XVI}^{\mathrm{e}}$ siècle, qu'elles ont permis aux populations autochtones de se réapproprier leur histoire et de signifier leur identité. Ces cultes réinventés sont ainsi aujourd'hui à la fois andins et chrétiens.

The author analyzes the historical and social process through which the appropriation and articulation of Catholic saints and virgins has occurred in the Andean region of Colombia. Within the framework of local religion, one finds the myths and rituals through which these images, introduced in the I6th century, have been used metaphorically by the native population to rappropriate their history. Thus reinvented, those cults are today both Andean and Christian.

\section{AUTOR}

\section{BEATRIZ NATES CRUZ}

Grupo de Investigación Territorialidades, Universidad de Caldas-Manizales - Colombia 